\title{
THE MANAGEMENT OF PIONEERING INCLUSION CLASS AT MI KARANG KEMIRI BANYUMAS CENTRAL JAVA
}

\author{
Roikhatul Janah \\ Sekolah Tinggi Agama Islam Nahdhatul Ulama Purworejo \\ Email: roikhatuljanah@stainupwr.ac.id
}

\begin{abstract}
Inclusive education is a service system in the world of education and teaching that combines students who have limitations with normal students in a regular class to get common knowledge from a teacher. Data shows that Banyumas District has more than 2000 students with special needs, Madrasah Ibtidaiyah (MI) 1, Karang Kemiri is a pilot MI to implement inclusive classes in Banyumas Regency. This study aims to find out how the inclusion class management strategies in the MI 1 Pakuncen Banyumas pioneering inclusion class. This research is a qualitative approach, with the focus of research on the inclusive class management strategies in the pioneering inclusion class of MI Karang Kemiri, Pakuncan, Banyumas. Inclusion class management strategies in MI 1 Karang Kemiri include the management of educators and the management of students.
\end{abstract}

\section{Kata Kunci: Inclusion class, Management of pioneering, Madrasah ibtidaiyah.}

\section{INTRODUCTION}

In the act of National Education System number 20 year 2003, education provides an opportunity for all students to develop their potential maximally. Indonesia is known as a plural nation because it has religious, language, tradition, and cultural plurality roots. ${ }^{1}$ Education in Indonesia has been regulated in a legal system to support the education system. However, it cannot be denied that education components as in every education unit certainly have a real difference. ${ }^{2}$ Students' plurality will be found in a classroom environment of an education system. Each student will come with differences. The difference seen from both real physical and mental limitations may occur on students.

National Education System or Act Number 20 the Year 2003 provides a similar opportunity to each student to develop his/her potential. However, in Indonesia many children are categorized as physically and mentally disabled. The limitation causes an

\footnotetext{
${ }^{1}$ Imran Rosyidi, Pendidikan Berparadigma Inklusif, (Malang: UIN-Maliki Press, 2009), p. 1.

2 Dian Apriani, "Konsep Pendidikan Islam Inklusif Perspektif K.H Abdurrahman Wahid" Skripsi (Salatiga: FTIK IAIN Salatiga, 2017), p. 4. 
issue in form of education and teaching rights equality as what is enjoyed by other normal children $^{3}$. It is proven by fewer education units that implement inclusion class.

Inclusion emerges as an approach to build and develop a more opened environment; ask and involve all people with various backgrounds, characteristics, competencies, statuses, conditions, ethnics, cultures, and religious. ${ }^{4}$ The education world should be able to apply the inclusion approach in its process so that the equality of the rights between education and teaching is obtained by them who have physical and mental limitations.

According to Mohammad Takdir Ilahi, inclusive education is an educational concept that represents all aspects that are related to openness and similarity in obtaining rights for children with special needs. ${ }^{5}$ Inclusive education is an education service system which requires children with special needs to study at nearest schools in the regular class with their peers. ${ }^{6}$ Based on the definition, it is understood that inclusive education is a service system in education and teaching world that equalizes every student so that they who have physical and mental limitations obtain equal rights to normal students.

National economic social survey data (Susenas) in 2012 found that Indonesia populations who are disabled (the concept of disability includes vision, hearing, communicating, memorizing/concentrating, walking/ walking upstairs, taking care of themselves disabilities) is $2.45 \%$. Based on the data, the government tries to improve the quality of education by opening the opportunity to all Indonesia children (without any exception) to study. The foundation of inclusive education in Indonesia is organized in the National Minister Regulation of Republic Indonesia Number 70 the Year 2009 Article 3 Paragraph. $^{7}$

According to Burhanuddin, et. al., classroom management is an effort process which is performed by educators to create and maintain conducive condition. ${ }^{8}$ Syaiful Bahri and Aswan Zain defined classroom management as the educator's skill to create,

${ }^{3}$ Khairisul Wathoni, "Implementasi Pendidikan Inklusi dalam Pendidikan Islam" Jurnal Ta'allum 1, no. 1 (2013): 99-109.

${ }^{4}$ Daksa foundation blog, accessed from daksa.blog

${ }^{5}$ Mohammad Takdir Ilahi, Pendidikan Inklusi Konsep dan Aplikasi (Yogyakarta: Ar-Ruzz Media, 2013), p. 27.

${ }^{6}$ Pedoman Penyelenggaraan Pendidikan Inklusi (Directorate of Special Education, Directorate of Primary and Junior High Education, Department of National Education Pendidikan Nasional, 2005).

${ }^{7}$ Regulation of National Education Minister of Republic Indonesia no. 70 Year 2009.

${ }^{8}$ Burhanuddin, et.al., Manajemen Pendidikan (Malang: Universitas Negeri Malang, 2003), p. 44. 


\section{Roikhatul Janah}

maintain, and restore the optimal learning condition. ${ }^{9}$ Based on the research, the researcher understands that classroom management is an effort that should be performed by educators or homeroom teachers (MI/Primary School) to create and maintain effective, efficient, and conducive conditions for classroom learning. Therefore, a classroom which is managed orderly to manifest an effective, efficient, and conducive condition. ${ }^{10}$ Classroom management is aimed to create qualified learning to improve the learning quality. So, the learning objective which is designed will be achieved.

The management of inclusion education strategy should at least cover three aspects, which are planning, implementation, and monitoring. The planning aspect covers the development of vision, mission, and objective of school, which is adjusted with the school and environmental condition. ${ }^{11}$ In the implementation aspect, the lesson plan is made based on the assessment result. While on the monitoring aspect (evaluation), inclusion school needs a method, time, and curriculum content adjustment. ${ }^{12}$

According to Tri, ${ }^{13}$ there are approximately 25 children with special needs at every school/madrasah. Based on the data in Banyumas, there are 2000 students with special needs who are found in 19 villages. Jamur Dwipa foundation takes initial action to overcome the issue, which is found based on the data by providing voluntary training towards madrasah teachers. ${ }^{14}$ One of madrasah that obtains specialized service training for children with special needs is MI Karang Kemiri, Pakuncen Sub-district, Banyumas Regency. MI Karang Kemiri is one of the private MI that tries to hold an inclusive education program. The program service delivery is an inial step to provide a service to some of their students who have to get special service in education. ${ }^{15}$ Based on the

${ }^{9}$ Syaiful Bahri Djamarah and Aswan Zain, Strategi Belajar Mengajar (Jakarta: PT. Rineka Cipta, 2006), p. 177.

${ }^{10}$ Suharsimi Arikunto, et.al. Penelitian Tindakan Kelas, (Jakarta: Bumi Aksara, 2007), p. 68.

11 Sukinah, "Manajemen Strategi Implementasi Pendidikan Inklusif" Jurnal Pendidikan Khusus 7, no. 2 (2010): 43.

12 Sunaryo, "Manajemen Pendidikan Inklusif (Konsep, Kebijakan, dan Implementasi dalam Perspektif Pendidikan Luar Biasa)" Journal of Public Administration DIA, (2009). downloaded from http://file.upi.edu/Direktori/FIP/JUR_PEND_LUAR_BIASA/195607221985031-

SUNARYO/jurnal_Inklusi.Pdf accessed at 30 Agustus 2019).

${ }^{13}$ Tri is Margono Purwokerto Hospital staff who handles Special Needs Children in Banyumas Regency and the person in charge of Jamur Dwipa foundation.

14 Ngopi (Ngobrol Pendidikan Islam), downloaded from http://banyumas.kemenag.go.id/berita/read/penelitian-pendidikan-inklusif-di-madrasah on 04/09/2019 at 12.33.

${ }^{15}$ Faidillah Wahyuning Tyas, one of classroom teachers of MI 1 Karang Kemiri. Interview on 29 Agustus 2019. 
explanation, the researcher researches the strategy of inclusion class management, which was carried out by Teacher of Grade III at MI Karang Kemiri Banyumas.

\section{RESEARCH METHODS}

The research utilized a qualitative approach which was done to perform in-depth exploration of programs, events, processes, and activities towards an individual or more. ${ }^{16}$ The researcher would observe and describe clearly and in detail to get in-depth data of research focus on inclusion class management strategy in pioneering inclusion class of MI 1 Karang Kemiri Pakuncen Banyumas. The primary data was in the form of verbal data, which was obtained from an interview with informants (teacher of Grade II, assistant teacher, and the head of the madrasah) was noted by the researcher in forms of written form and data which was obtained from direct observation. The researcher would dig and collect related to research focus by doing observation, interview, and documentation. The data analysis technique utilized by the researcher was Miles and Huberman's model, which contains data collection, reduction, presentation, and conclusion drawing. The data validation would be checked by data triangulation.

\section{RESULT AND DISCUSSION}

\section{The History of Inclusion Class Implementation at MI Karang Kemiri}

Inclusion class at MI Karang Kemiri has been prevailed programmatically, through the semester I in the academic year of 2019/2020. Although it has prevailed since this academic year, MI has tried to prepare the implementation of inclusion class since the academic year 2017/2018 as it is. In 2018, the educator staff or MI Karang Kemiri joined inclusion volunteer training, which was carried out by Jamur Dwipa Foundation of Banyumas Regency. The training provides knowledge and training on how to detect students with special needs as early as possible by reading and introducing letters towards students whose development age should have known letters. Further training was testing students by mentioning their classmates' names. It is continued by throwing and catching balls. Four educators who join the training start applying knowledge which is obtained from inclusion volunteer training to detect students of MI Karang Kemiri. Then, civil servant teachers of MI Karang Kemiri obtain inclusion classroom training from Ministry

\footnotetext{
${ }^{16}$ Sugiyono, Cara Mudah Menyusun Skripsi, Tesis dan Disertasi (Bandung: Alfabeta, 2013).
} 


\section{Roikhatul Janah}

of Religious Affairs (MORA) of Banyumas Regency. ${ }^{17}$ Besides participating the educator staff in some inclusion volunteer training, MI Karang Kemiri also has a human resource that supports the implementation of inclusion class. There are two educators have education qualification which is relevant to inclusion class, which are bachelor of Psychology and Guidance and Counseling. Besides possessing relevant qualifications, the educators also often join special inclusion training. Furthermore, in the implementation he/she becomes a special assistant teacher or called "Guru Pendamping Khusus" (GPK). ${ }^{18}$ Through the preparation by participating teachers in training, the inclusion class implementation is planned programmatically from Semester 1 in the academic year of 2019/2020. MI Karang Kemiri has 17 unique with special needs who are categorized in some categories. However, most of them are categorized as slow learning category. ${ }^{19}$

It is similar to Grade III, which is observed by the researcher. 3 of 4 students with special needs are categorized as low learning category. One of them is categorized as hyperactive students. ${ }^{20}$ They select the category of students with special needs by seeing three daily test scores and observation results towards students whose behaviors are indicated to have special attention, which is done by the classroom teacher. If the three scores of the daily tests are not relevant with standard and result of observation indicates that they are students with special needs and different to others, special treatment should be performed towards students who are indicated as children with special needs. ${ }^{21}$

\section{The Strategy of Inclusion Class Management on Grade III of MI Karang Kemiri}

The total students of grade II are 30 students, and the learning model which is utilized by them is a pull out classroom model or model which places students with special needs to learn together with normal students in regular class to join all teaching given by the teacher of grade III. Students who are categorized as ADHD are children who have a different style of studying. Classroom teachers and individual assistant teacher performed early detection towards them when they were on grade II by doing an observation. The observation result indicates the difference in students' studying style. Other students can study clamly on their table, these students will study under the table, write while sitting

\footnotetext{
${ }^{17}$ Interview with teacher of Grade III.

${ }^{18}$ Interview with the head of Madrasah.

${ }^{19}$ Interview with the head of Madrasah.

${ }^{20}$ Interview with teacher of Grade III.

${ }^{21}$ Interview with teacher of Grade III.
} 
on the table, write or read while walking around, or suddenly leave the class when the teacher is explaining the lesson. All assignments must be dictated directly by the teacher to the students because their attention is easily distracted by something. Based on the observation result, the students of grade II are categorized as ADHD. ${ }^{22}$

The initial step of handling students with ADHD category is teacher builds good communication with parents and the student to explain the condition which occurs towards the child. From Grade II to II, the teacher always actively gives information on the development of the child with the ADHD category. The classroom teacher does not prohibit how the students study but still monitors their activities. In order to achieve the learning objective of every meeting, the classroom teacher patiently and carefully assists with the lesson. The assistance is given if the ADHD student has not completed the learning achievement on lesson which is given by classroom teacher.

Teachers always give oral or written instruction. The researcher finds that the classroom teacher writes an instruction on the ADHD student's book. ${ }^{23}$ After the researcher confirms it, the teacher explains that by adding instruction sentence on the student's book, he/she can directly respond to what is intended. ${ }^{24}$ For normal students, the instruction is given in writing on board or orally. Since students of ADHD ignore the instruction if it is delivered as normal children. Assignments are given equally with the same topic, but ADHD students take a longer time to complete. Indeed, they are assisted by either classroom teacher or peers to complete the assignment several times. The existence of ADHD students in regular classes does not influence or distract teachinglearning activities. The teaching-learning activities run as a lesson plan, which is made by the classroom teacher. ${ }^{25}$ ADHD students do not distract other students. They make themselves busy and often walk around the class. They also have a different learning styles with their normal friends.

Three of four students with special needs on Grade II of MI Karang Kemiri are categorized as slow learning. Problems that are faced by them are reading and mathematics difficulty. It is similar to ADHD students, and early detection was performed when they were in grade II. Early detection of the three slow learning students was done

\footnotetext{
${ }^{22}$ Interview with teacher and special assistant teacher of Grade III.

${ }^{23}$ Observation Result on 29 August 2019.

${ }^{24}$ Interview with teacher of Grade III.

${ }^{25}$ Interview with teacher of Grade III.
} 


\section{Roikhatul Janah}

by observing every daily test, which was done by them. After finding that three daily test scores are far below KKM (Minimum Criteria of Mastery Learning) of each lesson, the classroom and assistant teachers will perform observation towards them and give them a simple test on letter introduction. According to the letter introduction, the three students can understand alphabet letters as a whole, although the teacher should remind some letters. After the letter introduction, the three students are tested for reading series vocal and consonant letters. On this test, the three students are found to have difficulty to read a series of vocal and consonant letters. As a result, they face difficulty to get score higher than KKM of all lessons.

The initial step of handling slow learning children when they are on grade II is by using the method of reading practice drilling of vocal and consonant letters series. However, daily test or Mid Semester Test and Final Semester Test do not indicate positive change. The classroom teachers deliver the issue to individual assistance teacher for Children with special needs in order to further discuss strategies that will be implemented. When they are on grade III, classroom and individual assistant teachers handle the three students by giving additional time outside lesson hours to get practice and assignment of reading and other lessons that must be completed every day by the students. The implementation of lesson hour addition is done after school for 30 minutes. When they finish school time, the classroom and individual assistant teachers will give more homework, so there will be a change in understanding the level of each learning material although they still have difficulty reading. ${ }^{26}$

Mostly, the grade III class condition is well managed by classroom teachers although several students are in the special needs category. Based on the classroom teacher, there is no bullying case towards them. Even though until the present, it has not been fully recognized by normal students that MI Karang Kemiri implements an inclusion class program. The learning style differences between regular and special needs students do not make the normal students do bullying or complain about a distraction with them to the classroom teachers.

The school uses the same curriculum management for regular or special needs students. The difference is how to implement the curriculum on students with special

\footnotetext{
${ }^{26}$ Result of Interview and observation with teacher of Grade III on 29 August 2019.
} 
needs. The strategies and methods utilized are more or less the same, but the personal approach is prioritized by the classroom teacher.

The management of educators and the educational staff of MI Karang of Karang Kemiri in implementing inclusion class is by participating them in inclusion class training. In the future, the head of the madrasah also has a plan to invite Tri from Jamur Dwipa foundation of Banyumas Regency to provide training and development concerning inclusion education.

Including class pioneering at MI Karang Kemiri has not entirely run well and smoothly. However, MI Karang Kemiri, with their limitations (facility and infrastructure, finance, and educational staff that support inclusion class) is brave to implement inclusion class. The implementation of inclusion class based on the needs analysis of students who are detected as special needs students.

\section{CONCLUSION}

Grade III of MI Karang Kemiri, Pakuncen Sub-district, Banyumas Regency has four students with special needs with one of the students who is categorized as ADHD, and the other three students are categorized as low learning category. The student's management strategy, which is performed in a pioneering inclusion class at MI Karang Kemiri includes managing students with early detection by using various tests to categorize them who have special needs. Furthermore, the management is performed by the educator and educational staff. MI Karang Kemiri provides an opportunity so that the educator and educational staff follow inclusion class management training. In the implementation of learning, a good personal approach, and communication between madrasah and family of students with particular need are built.

\section{REFERENCES}

Apriani, Dian. (2017). "Konsep Pendidikan Islam Inklusif Perspektif K.H Abdurrahman Wahid” Skripsi. Salatiga: FTIK IAIN Salatiga.

Arikunto, Suharsimi. et.al. (2007). Penelitian Tindakan Kelas. Jakarta: Bumi Aksara. Burhanuddin, et.al. (2003). Manajemen Pendidikan. Malang: Universitas Negeri Malang. Daksa foundation blog, accessed from daksa.blog 


\section{Roikhatul Janah}

Djamarah, Syaiful Bahri \& Aswan Zain. (2006). Strategi Belajar Mengajar. Jakarta: PT. Rineka Cipta.

Ilahi, Mohammad Takdir. (2013). Pendidikan Inklusi Konsep dan Aplikasi. Yogyakarta: Ar-Ruzz Media.

Ngopi (Ngobrol Pendidikan Islam), downloaded from http://banyumas.kemenag.go.id/berita/read/penelitian-pendidikan-inklusif-dimadrasah on $04 / 09 / 2019$ at 12.33 .

Pedoman Penyelenggaraan Pendidikan Inklusi. (2005). Directorate of Special Education, Directorate of Primary and Junior High Education, Department of National Education Pendidikan Nasional.

Regulation of National Education Minister of Republic Indonesia no. 70 Year 2009.

Rosyidi, Imran. (2009). Pendidikan Berparadigma Inklusif. Malang: UIN-Maliki Press.

Sugiyono. (2013). Cara Mudah Menyusun Skripsi, Tesis dan Disertasi. Bandung: Alfabeta.

Sukinah. (2010). "Manajemen Strategi Implementasi Pendidikan Inklusif" Jurnal Pendidikan Khusus 7, no. 2: 43.

Sunaryo. (2009). "Manajemen Pendidikan Inklusif (Konsep, Kebijakan, dan Implementasi dalam Perspektif Pendidikan Luar Biasa)" Journal of Public Administration DIA. downloaded from http://file.upi.edu/Direktori/FIP/JUR_PEND_LUAR_BIASA/195607221985031SUNARYO/jurnal_Inklusi.Pdf accessed at 30 Agustus 2019).

Wathoni, Khairisul. (2013). "Implementasi Pendidikan Inklusi dalam Pendidikan Islam" Jurnal Ta'allum 1, no. 1: 99-109. 
The Management of Pioneering Inclusion Class at MI Karang Kemiri Banyumas Central Java 